\title{
A quebra de paradigmas religiosos em tempos de pandemia: dos templos para as casas e para as mídias
}

\author{
The breaking of religious paradigms in times of pandemic: \\ from temples to homes and the media
}

\author{
Valdir Stephanini* \\ Julio Cezar de Paula Brotto**
}

https://doi.org/10.29327/256659.12.1-5

\section{Resumo}

Este artigo se propõe a fazer uma reflexão sobre a relação que há entre a pandemia do novo corona vírus e a quebra de paradigmas nas religiões, sobretudo das igrejas cristãs. A partir do conceito de paradigma, proposto por Thomas S. Khun, busca-se mostrar que, mais do que tragédias, as principais pandemias vividas pela humanidade na era cristã impuseram a necessidade das igrejas cristãs quebrarem paradigmas a fim de atenderem as demandas da sociedade e, sobretudo, as demandas das próprias comunidades. O objetivo central do artigo é mostrar que a quebra de paradigmas é também uma oportunidade que as igrejas tem de rever suas convicções e suas práticas, especialmente na superação do templocentrismo e na utilização das novas tecnologias que permitem acesso às novas mídias disponiveis na sociedade contemporânea. A questão problema que se tenta responder é até que ponto as igrejas cristãs estão aproveitando esses momentos de crise aguda, vivido pela humanidade, para resgatar paradigmas perdidos, presentes no cristianismo primitivo e implementar novos paradigmas diante das oportunidades que se abrem com as novas tecnologias. A primeira seção fará uma abordagem histórica, pontuando alguns acontecimentos vividos pela humanidade na pandemia conhecida como peste bubônica ou peste negra (1346 a 1352) e na grande gripe, conhecida também como gripe espanhola (1918 a 1920). Na segunda seção serão apresentados alguns conceitos de paradigma e a necessidade da quebra de paradigmas nas pandemias, sobretudo naquela vivida pela humanidade nesse início do século 21 . Na terceira seção serão mostradas algumas medidas tomadas pelas igrejas cristãs das diversas denominações, em virtude da pandemia da COVID-19, relacionada com a quebra de paradigmas.

Palavras chaves: Pandemia.Paradigma.Igrejas cristãs.Casas e mídias.

\footnotetext{
* Doutor em Teologia pela Pontificia Universidade Católica do Rio de Janeiro (PUC-Rio). Docente do Programa de Pós-Graduação em Ciências das Religiões da Faculdade Unida de Vitória (FUV). Email: valdir@fuv.com.br.

** Doutor em Teologia pela Pontificia Universidade Católica do Rio de Janeiro (PUC-Rio). Docente do Programa de Pós-Graduação em Ciências das Religiões da Faculdade Unida de Vitória (FUV). Email: julio.brotto@fuv.com.br.
} 


\begin{abstract}
This article proposes to reflect on the relationship that exists between the pandemic of the new coronavirus and the breaking of paradigms in religions, especially in Christian churches.Based on the concept of paradigm, proposed by Thomas S. Khun, we seek to show that, more than tragedies, the main pandemics experienced by humanity in the Christian Era imposed the need for Christian churches to break paradigms in order to meet the demands of society and, above all, the demands of the communities themselves.The main objective of the article is to show that breaking paradigms is also an opportunity that churches have to review their convictions and practices, especially in overcoming templocentrism and in using new technologies that allow access to new media available in contemporary society.The problem question we are trying to answer is the extent to which Christian churches are taking advantage of these moments of acute crisis, experienced by humanity, to rescue lost paradigms, present in primitive Christianity and implement new paradigms in the face of the opportunities that are opened up with new technologies. The first section will take a historical approach, highlighting some events experienced by humanity in the pandemic known as bubonic plague or black plague (1346 to 1352) and in the great flu, also known as the Spanish flu (1918 to 1920).In the second section, some paradigm concepts and the need to break paradigms in pandemics will be presented, especially in that experienced by humanity at the beginning of the 21 st century.In the third section, some measures taken by the Christian churches of the different denominations will be shown, due to the COVID - 19 pandemic, related to the paradigm break.
\end{abstract}

Key words: Pandemic.Paradigm. Christian churches.Houses and media.

\title{
Introdução
}

A pandemia da COVID-19, doença causada pelo vírus SARS-Cov2, da familia de coronavírus descoberta nos anos 1960, pegou todo mundo de surpresa e alterou significativamente a rotina de todas as pessoas, causando apreensão, medo, angústia, perdas, muito sofrimento e forçou a quebra de paradigmas em todos os níveis da sociedade, inclusive nas religiões, preponderantemente nas igrejas cristãs.

Habituadas a utilizarem espaços específicos dedicados aos seus rituais, as religiões, sobretudo as igrejas cristãs, foram forçadas, de um momento para outro, sem planejamento algum, a quebrar paradigmas e a se reinventarem na busca do atendimento de seus fiéis, passando a utilizar as casas e as novas tecnologias para manter seus membros unidos e atender as demandas trazidas pela pandemia.

Certamente o grande diferencial, se comparada com as pandemias anteriores, está sendo a utilização das mídias, por parte das religiões, no processo de comunicação, caminhando assim para um novo paradigma que deve se manter no período pós-pandemia.

A última grande pandemia vivida pela humanidade havia ocorrido há mais de um século, conhecida como gripe espanhola, apesar de ter se manifestado na 
Filadélfia, tendo aparecido em 1918 e se mantido até 1920, "matando mais pessoas do que qualquer outro surto de doença na história da humanidade" (Barry,2020, p. 12). Claro que naquela pandemia também as religiões precisaram se adaptar, mas não contavam com as novas tecnologias presentes na realidade da pandemia da COVID-19.

Segundo Peter Berger (1995, p. 15): "Toda sociedade humana é um empreendimento de construção do mundo. A religião ocupa um lugar destacado nesse empreendimento". Sendo assim, num tempo de pandemia, em que toda a humanidade é afetada, as religiões acabam tendo um papel importante, tanto positiva quanto negativamente, quando promovem redes de solidariedade para o suprimento das demandas da população sofrida, ou quando fazem uma leitura negacionista da realidade, colocando os fiéis em risco ao manterem suas reuniões e promoverem aglomerações proporcionando a disseminação do vírus com muito mais intensidade.

Esse artigo se propõe a mostrar que, além de todas as dificuldades e sofrimentos causados pela pandemia da COVID-19, esta se constitui numa oportunidade para que as religiões quebrem seus paradigmas e busquem novas formas de agir e interagir com a sociedade.

\section{As religiões diante das pandemias ao longo da história}

Embora esteja causando danos irreversiveis em todo o mundo, a pandemia da COVID-19 não é a primeira a ser vivida pela humanidade. Dentre as muitas pandemias que foram enfrentadas ao longo da história, duas serão destacadas nesse artigo: A Peste Bubônica e a Gripe Espanhola.

\section{A PesteBubônica}

A pandemia Peste Bubônica, também conhecida como Peste Negra, em virtude dos corpos das vítimas assumirem coloração escura (Barry, 2020, p. 246; Martino, 2017, p. 32), embora esse termo só tenha sido utilizado a cerca de duzentos anos depois do fim da pandemia (Martino, 2017, p. 30), assolou a Ásia e a Europa entre os anos de 1346 a 1352 e matou "um terço da população, ou seja, cerca de 25 milhões de pessoas" (Martino, 2017, p. 90). Embora tenha desaparecido em 1352, "porém até o século XVIII, a peste permaneceu em estado endêmico na Europa, retornando sem muita violência de tempos em tempos, até que as 
pessoas, finalmente, conseguiram desenvolver anticorpos para se defender da doença" (Martino, 2017, p. 90).

Tratava-se de uma doença contagiosa, que atingiu grande parte da população já penalizada com a escassez de alimentos, uma vez que trinta anos antes milhares de europeus tinham morrido de fome em virtude do excesso de chuvas que haviam comprometido as colheitas. Os resultados foram desastrosos. "Os negócios paralisaram-se e muitos comerciantes faliram. Escolas e universidades fecharam as portas, por falta de pessoal capaz de dirigir. [...] Grande número de aprendizes deixou de concluir sua aprendizagem resultando num empobrecimento profissional" (Martino, 2017, p. 31-32). Martino cita o médico muçulmano Ibn Al-Khatib que teria descrito a peste como sendo: "uma doença aguda, acompanhada de febre em seu início, de essência tóxica, que atinge o coração, através do ar, espalha-se pelas veias e corrompe o sangue, e confere a certos humores característica venenosa, o que gera a febre e a expectoração de sangue" (2017, p. 32).

Nesse tempo de pandemia, a religião Católica era predominante na Europa e a Igreja comandava as ações da sociedade em toda e qualquer circunstância. Acreditava-se que a vida terrena era apenas um detalhe, porque o mais importante era a vida eterna. Praticamente todas as pessoas acreditavam na existência de um Deus bom e misericordioso e na existência de uma vida depois da morte. Mesmo assim, "quando ocorria alguma calamidade, como a peste negra, acreditava-se que era Deus quem estava punindo os homens ou os provando. Para aplacar a sua cólera, as pessoas deviam jejuar, fazer penitências, orar e realizar atos de caridade" (Martino, 2017, p. 28).

Quando a pandemia alcançou o continente europeu, em 1347, era Clemente VI quem liderava o mundo cristão, não de Roma, mas de Avignon, para onde a sede do papado havia sido transferido recentemente. Ele foi aconselhado pelo seu médico particular a abandonar a cidade e refugiar-se no campo, numa tentativa de se livrar da peste, prática seguida pela população que achava que refugiando-se no interior, estariam livres da doença, o que na verdade era ilusão, pois a enfermidade atingiu também a zona rural. (Martino, 2017, p. 31, 32 e 38).

As interpretações acerca do que estava acontecendo eram muitas e desencontradas. As especulações sobre as causas para tamanha tragédia iam desde a crença de que Deus estava punindo a população por causa dos seus pecados, o fato de a sede do governo papal ter sido transferida de Roma para Avignon até a 
presença dos judeus em terras europeias, ajudados pelos leprosos (Martino, 2017 , p. 32). Como os médicos podiam fazer muito pouco em favor dos pacientes e ninguém sabia com certeza como a doença se expandia e, muito menos, como se livrar dela, restava para o povo apegarem-se aos santos de sua devoção.

Segundo Martino, "foi o cientista suíço Alexandre Yersin quem primeiro descreveu corretamente o bacilo da peste. [...] O vetor do bacilo Yersinia pestis é a pulga do rato-preto, a Xenopsylla cheopis, que é muito resistente e pode viver um ano inteiro sem encontrar um rato hospedeiro" (2017, p. 34). Foram identificadas pelo menos três maneiras de ataque da doença: a peste pneumônica, que atinge os pulmões, a peste septicêmica, que se manifesta na corrente sanguínea e a peste bubônica, nome derivado dos bubões, espécie de tumores escuros que apareciam, principalmente na região das axilas e virilhas. (Martino, 2017, p. 36).

As narrativas do que aconteceu nesse periodo é impactante. Doentes infectados não eram tratados porque as pessoas tinham medo de se contaminarem. Muitas vezes eram abandonados e acabavam morrendo sozinhos. Em outras situações, os doentes eram jogados para fora dos muros das cidades, a exemplo do que se fazia com os leprosos. Como não se sabia exatamente como tratar a doença, diversas iniciativas eram tomadas, desde acender fogueiras nas ruas, piras nas residências e queimar galhos secos que tivessem cheiro forte como pinho, alecrim, louro, cipreste e videira e, como não poderia deixar de ser, "os padres aconselhavam portar amuletos religiosos" (Martino, 2017, p. 42).

O destino que se dava aos defuntos era desesperador. Num primeiro momento, enquanto eram poucos os infectados, a população manteve os rituais de sepultamento, sempre que possivel, enterrando os corpos em covas bem fundas para não correr o risco de contaminar outras pessoas. Quando o número de óbitos se multiplicou, esses rituais foram abandonados.

Os cadáveres eram simplesmente recolhidos de manhã em carre-
tas que circulavam pelas ruas das cidades a fim de levar os doen-
tes que haviam falecido durante a noite, para serem sepultados
em cemitérios, em vala comum [...] emplilhando-se um defunto
por cima do outro sem sequer lhes envolver os corpos em uma
mortalha. [...] Os coveiros tornaram-se insuficientes para dar con-
ta de tanto trabalho, sem dizer que eles também iam morrendo,
como o restante da população (Martino, 2017, p. 48).

São poucas as informações sobre a maneira que a Igreja Católica enfrentou a pandemia, até porque vivia um momento de crise profunda, com a sede do papado localizada em Avignon, na França, sob a liderança de um papa que se 
preocupava mais com sua própria segurança e em desfrutar dos benefícios que o papado lhe oferecia (Martino, 2017, p. 77).

\section{A Gripe Espanhola}

Mais de 500 anos depois do fim da pandemia que vitimou milhares de pessoas, outra pandemia se instala e veio a se tornar mais letal em número de vítimas fatais. Claro que nesse período intermediário ocorreram muitos eventos epidêmicos ao redor do mundo, especialmente na Europa (Martino, 2017, p. 90). Barry registra o início da pandemia do início do século $\mathrm{XX}$, conhecida como gripe espanhola, da seguinte maneira:

Em 1918, surgiu um vírus influenza - provavelmente nos Estados Unidos - que se espalharia pelo mundo, e uma de suas primeiras aparições em forma letal ocorreu na Filadélfia. Antes de desaparecer em 1920, essa pandemia mundial mataria mais pessoas do que qualquer outro surto de doença na história da humanidade.

A humanidadeainda vivia na sombra de uma guerra mundial e agora precisava enfrentar uma enfermidade desconhecida que ameaçava a todos/as pela rapidez com que se espalhava e a letalidade com que dizimava aqueles/as que eram contaminados/as. Segundo Barry, "a estimativa mais baixa de fatalidades dessa pandemia em todo o mundo é de 21 milhões de pessoas [...]. Os epidemiologistas de hoje estimam que a gripe provavelmente causou ao menos cinquenta milhões de mortes em todo o mundo, e, possivelmente, até cem milhões" (2020, p. 12).

Um dado interessante sobre a pandemia da gripe espanhola é que, ao invés de atingir principalmente idosos e crianças, "aproximadamente metade dos que morreram eram homens e mulheres jovens no auge da vida, na faixa dos vinte aos trinta anos" Barry, 2020, p. 13). Uma explicação plausivel sobre isso seria pelo fato de que o vírus espalhou-se especialmente nos aglomerados de soldados que participavam da guerra, mas isso é apenas uma especulação.

Outro detalhe interessante é a rapidez com que o virus se espalhou e o número de vítimas fatais que ocasionou. Barry afirma que

Embora a pandemia de gripe tenha se prolongado por dois anos, talvez dois terços das mortes tenha ocorrido em período de 24 semanas, e mais da metade dessas mortes se deu em menos tempo, de meados de setembro a início de dezembro de 2018. A gripe matou mais pessoas em um ano do que a peste bubônica da Idade 
Média em um século; matou mais pessoas em 24 semanas do que a AIDS em 24 anos (Barry, 2020, p. 13).

As narrativas dos fatos que marcaram a pandemia da gripe espanhola na cidade de Filadélfia, que era um retrato do que acontecia no restante do mundo, ganha contornos de desespero trágico.

Os corpos foram postos em funerárias, ocupando cada área dessas instalações e se acumulando em alojamentos; em necrotérios de hospitais, já invadindo os corredores; nos necrotérios da cidade, já invadindo as ruas. E havia corpos nas casas também. Estavam na varanda, no armário, nos cantos do chão, nas camas. As crianças fugiam da vista dos adultos para observá-los, tocá-los.; as mulheres deitavam ao lado do marido morto, sem querer mexer no corpo ou deixá-lo. Os corpos, lembretes da morte e responsáveis por trazer terror e dor, repousavam sobre o gelo a temperaturas semelhantes às do verão na índia. A presença deles era constante, um terror desmoralizante para a cidade; um horror do qual não era possivel escapar (Barry, 2020, p. 372).

Além de todos os dramas inerentes à pandemia, pairava no ar uma disputa entre a concepção da ciência e da religião sobre o que poderia ser feito para inibir a disseminação do vírus e determinar o fim da pandemia. "Foi o primeiro grande choque entre uma força natural e uma sociedade com indivíduos que se recusavam a se submeter a essa força ou a simplesmente implorar por salvação através da intervenção divina" (Barry, 2020, p. 14). De positivo a se destacar foi a iniciativa da Igreja Católica em se unir as autoridades públicas a fim de recolher os corpos dos mortos. O fato é que somente os agentes públicos não conseguiam dar conta desse desafio. Os coveiros não davam conta de enterrar os mortos

e as próprias famílias dos mortos pegavam a enxada e escavavam a terra, os rostos marcados por suor, lágrimas e areia. [...] Seminaristas se voluntariaram para ser coveiros, mas ainda não conseguiam alcançar o ritmo. A cidade e a arquidiocese recorreram a equipamentos de construção usando pás a vapor para escavar valas comuns destinadas a enterros em massa. [...] O arcebispo Denis Doughterty enviou padres para as ruas a fim de remover os corpos das casas" (Barry, 2017, p. 372).

O isolamento tornou-se ainda mais dramático quando a empresa de telefonia ampliou o isolamento impedindo que 1800 funcionários ficassem sem trabalhar, exigindo que as chamadas fossem atendidas de maneira aleatória, impedindo assim uma comunicação que já era precária entre as pessoas. Barry cita Clifford Adams que afirmou: "As pessoas foram impedidas de se comunicar, de ir 
a igrejas, as escolas fechadas [...] todos bares fechados [...] tudo estava quieto" (Barry, 2020, p. 374).

\section{A mudança de paradigmas como elemento de renovação das religiões}

Esta seção tratará do conceito de paradigmas e analisará a necessidade de mudança de paradigmas para a renovação das religiões, sobretudo das igrejas cristãs, objetos desse artigo. Será observado também que as pandemias, particularmente a pandemia do novo corona virus, representam boas oportunidades para a quebra de paradigmas e consequente renovação das instituições religiosas.

\section{O significado de paradigma}

Desde que Tomas S. Kuhn utilizou a expressão em seu livro A Estrutura das Revoluções Científicas, publicado pela primeira vez em 1962, que passou a ser referência no trato do assunto, o termo vem sendo utilizado, pensado e repensado. Para Kuhn, um paradigma pode ser visto em dois sentidos diferentes:

\footnotetext{
de um lado, indica toda aconstelação de crenças, valores, técnicas etc., partilhadas pelos membros de umacomunidade determinada. De outro, denota um tipo de elemento dessaconstelação: as soluções concretas de quebra-cabeças que, empregadas comomodelos ou exemplos, podem substituir regras explícitas como base para asolução dos restantes quebra-cabeças da ciência normal(Kuhn, 2013, p. 187).
}

Pensando em termos de comunidades religiosas cristãs, paradigmas podem ser entendidos como o conjunto de doutrinas e práticas que tem sido por elas adotadas ao longo dos séculos, a partir das doutrinas e práticas das primeiras comunidades do movimento cristão, registradas nas Escrituras dos discípulos e discípulas de Jesus Cristo como também nas construções históricas desse movimento ao longo desses dois mil anos.

Outro teórico a conceituar paradigmas foi Joel Arthur Barker. Para ele, trata-se do "conjunto de regras e regulamentos (explícitos e não explícitos) que fazem duas coisas: 1)estabelecem limites ou fronteiras; 2) nos dizem como devemos nos comportar dentro destes limites de forma a sermos bem sucedidos" (1992, p. 32). A partir do conceito de Barker, os paradigmas cristãos são as regras e regulamentos que foram estabelecidos ao longo da história e que representam limites até onde se pode ir ou não a fim de cumprir a missão estabelecidas pelo Cristo. 
Ed René Kivitz, que faz uma aplicação do conceito de paradigma para a realidade do cristianismo, entende paradigma como sendo

A fronteiras dentro das quais o sucesso deve ser construído e as soluções dos problemas devem ser encontradas. Paradigmas são limites de possibilidades. Paradigmas são "verdades" que se fixaram na mente e que indicam um jeito de ser, viver ou fazer as coisas. Novos paradigmas surgem quando alguém descobre um jeito diferente de encarar ou fazer algumas coisas. (Kivitz, 2002, p. 12).

Conquanto aconteçam sem planejamento e sem intencionalidade, as pandemias se constituem oportunidade para que as comunidades religiosas descubram maneiras diferentes de encarar e de fazer algumas coisas, abrindo espaço para novos paradigmas. Afinal, segundo Edgar Morin, "quando o inesperado se manifesta, é preciso ser capaz de rever nossas teorias e ideias, em vez de deixar o fato novo entrar a força na teoria incapaz de recebê-lo" (2001, p. 30). Isso nos leva a pensar na quebra de paradigmas religiosos proporcionado pelas pandemias.

\section{A quebra de paradigmas nas pandemias}

Ao analisar os acontecimentos vivenciados pelos cristãos nas grandes pandemias, percebe-se que, em função do tamanho das crises, paradigmas religiosos cristãos foram quebrados, em função do periodo de excepcionalidade que se instalou na sociedade.

Nos anos da peste negra, por exemplo, pode-se mencionar a mudança nos rituais fúnebres, de cunho religioso, praticado pelos cristãos. Antes da chegada da peste, depois de um período de lamento feito pelas mulheres mais próximas ao defunto,

o falecido era conduzido à igreja que escolhera momentos antes de morrer. Os seus pares levavam-no aos ombros, com pompa fúnebre, de velas e de cantos. Tais cerimônias quase se extinguiram, no todo ou parcialmente, quando principiou o furor da peste. $\mathrm{E}$ muitas novidades vieram a substituí-las. [...] Fazia-se raro o caso daqueles que tinham, indo para a igreja, para o cortejo de dez ou doze de seus vizinhos. O féretro destes era carregado, não por honrados e prestimosos cidadãos, porém por uma espécie de padioleiros, que se originaram da gente mais humilde, que recebiam o título de coveiros, e que apenas usavam seus préstimos por um preço combinado com antecedência. [...] Os padioleiros caminha- 
vam atrás de quatro ou cinco clérigos, com raras velas; as mais das vezes iam mesmo sem nenhum clérigo (Martino, 2017, p. 48).

Ainda que se tenha poucas informações de outras práticas que foram quebradas pelos cristãos nesse período, a prática da alteração dos rituais de sepultamento serve como exemplo de que em periodos de excepcionalidade, como o vivido pela humanidade na Idade Média, a quebra de paradigmas religiosos, não só se configura como tal,como significae identifica uma oportunidade para a reflexão sobre a real importância destes paradigmas na vida das comunidades.Poder-se-ia questionar se a quebra de paradigmas religiosos ou a quebra de paradigma das comunidades religiosas tem importância na vida destas comunidades ou até mesmo de outras comunidades? É provável que a firmação possa ser sim na medida em que toda quebra ou ruptura gera novas possibilidades hermenêuticas de compreensão da vida e também da morte. Heidegger afirma que a base fundamental da linguagem não se encontra na lógica nem na gramática, e muito menos no potencial do aparelho fonador do animal racional, mas baseia-se na composição existencial do ser-aí, isto é, na abertura do ser-nomundo. (Heidegger, 1998, p. 35).

$\mathrm{Na}$ pandemia da gripe espanhola, além de serem impedidos de se reunirem nas igrejas, os cristãos e as cristãs se envolveram de maneira extraordinária na tentativa de amenizar o sofrimento das famílias e resolver os problemas relacionados aos enfermos e aos falecidos. Como exemplo dessa mudança, pode-se mencionar o que aconteceu com as freiras, que antes enclausuradas com regras rígidas de comportamento, agora foram liberadas para deixar a clausura e quebrar os votos dantes feitos.Barry menciona que, numa atitude desesperada para ajudar "o arcebispo liberou freiras para trabalharem nos hospitais, incluindo os hospitais judeus, e permitiram que elas violassem as regras das ordens religiosas de passar a noite fora do convento e quebrar votos de silêncio" (2020, p. 374).

Mesmo fora das pandemias, Kivitz propõe a necessidade da quebra de quatro paradigmas que se encontram cristalizados nas comunidades cristãs contemporâneas e que deveriam ser modificados para sua renovação, resgate do genuíno conceito de Igreja e cumprimento de sua missão no mundo. Segundo ele há uma "mentalidade vigente, uma certa maneira de pensar a igreja, que se torna representativa da grande maioria das comunidades cristãs, que pode ser identificada à luz de quatro grandes paradigmas, a saber: culto, clero, domingo e templo" (2002, p. 39). Segundo Kivitz esses quatro paradigmas têm causado danos ao cristianismo porque "viciaram a mente do cristão a compreender a Igreja como 
um acontecimento semanal" (2002, p. 39-40). Kivitz defende a tese de que "o ensinamento bíblico é que a Igreja do Senhor Jesus está desafiada a viver além dos limites do culto-clero-domingo-templo" (2002, p. 40).

Num momento de pandemia, como a vivenciada nesse momento com a COVID-19, a rotina das Igrejas precisou ser alterada. Com atividades concentradas aos domingos e centralizadas nos templos, as Igrejas precisaram se adequar ao momento, obedecendo às recomendações das autoridades de saúde, tendo que fechar os templos e utilizar estratégias alternativas para atender as demandas dos membros das comunidades.

Um dos movimentos que acabou acontecendo, mesmo que de maneira forçada, foi a valorização das casas, motivada pela quarentena, retornando a uma prática muito comum entre os cristãos nos primeiros séculos, como se lê nas narrativas das Escrituras: "E, perseverando unânimes todos os dias no templo, e partindo o pão em casa, comiam com alegria e singeleza de coração" (Atos 2, 46). As casas dos membros das igrejas eram utilizadas pelos discípulos e discípulas de Jesus Cristo para reunir-se e celebrar a comunhão cristã. " $E$ todos os dias, no templo e de casa em casa, não cessavam de ensinar e de anunciar Jesus Cristo" (Atos 5, 42).

Howard Snyder afirma que "cristãos judeus continuaram cultuando por algum tempo no templo, mas essa prática foi cessando gradativamente. E o templo foi destruído em 70 d.C." (1977, p. 70). Segundo Snyder, "teologicamente, a igreja não precisa mais de templos. Edifícios não são essenciais para a verdadeira natureza da igreja, pois o tabernáculo simbolizava a habitação de Deus, e Deus já habita dentro da comunidade humana dos crentes cristãos" (1977, p. 70). A necessidade de templos passou a ser sentida depois de 200 anos de história do movimento cristão (Snyder, 1077, p. 74). Isso significa dizer que, embora os espaços conhecidos como templos tenham sua utilidade prática, é perfeitamente possivel as igrejas cristãs existirem e cumprirem sua missão, mesmo sem as tradicionais reuniões aos domingos, dirigidas por um pastor, num culto, no templo. E isso tem sido evidenciado nesse periodo de pandemia, em que as igrejas passaram a utilizar as casas como refúgio para os seus membros e as mídias como estratégia para a divulgação do Evangelho e as orientações às comunidades, como será exaustivamente demonstrado na próxima seção.

\section{Ações e reações das religiões diante da pandemia da COVID-19}


Em busca de mudanças e adequações neste tempo de pandemia, as religiões, por meio do arcabouço e dinâmica própria de cada uma, assumiram vultosa intensidade no ciberespaço por meio das tecnologias, gerando uma enorme pandemia de transmissões religiosas: doutrinas, ritos, valores, celebrações, estudos, comunicações etc. Neste panorama de mudanças rápidas nas atividades religiosas impostas pela pandemia da COVID-19, o distanciamento fisico em busca de boas práticas higiênicas, demandou das lideranças religiosas alternativas para manterem os laços relacionais e religiosos e assistirem religiosamente os fiéis.

Embora essa prática não seja inédita, uma vez que "em geral, as igrejas nunca rejeitaram as mídias, pelo contrário" (Cunha, 2017, p. 27) as tem utilizado em profusão desde suas origens, não resta dúvidas de que a pandemia intensificou essa utilização e consolidou a quebra do paradigma do templo, uma vez que, segundo Freire,

\begin{abstract}
os milhares de sites, blogs e perfis em redes sociais que tem a religião como tema fundador, oferecem, basicamente, discursos nos formatos mais diversos, desde textos e vídeos até aplicativos e imagens animadas, porém, em nossa percepção, os espaços virtuais que mais caracterizam os ciber-templos seriam as páginas que possibilitam a participação e interação com os fiéis(Freire, 2017, p. 148).
\end{abstract}

A partir do início da pandemia do novo coronavirus, no início de 2020, com a necessidade de fechamento dos templos em função dos riscos de contaminação, os meios midiáticos vêm sendo utilizados pela maioria dos líderes religiosos ao redor do mundo, para darem continuidade às atividades religiosas, possibilitando os fiéis, até os que não têm acesso aos recursos tecnológicos por uma variedade de razões, com o objetivo de minimizar a falta das celebrações nos espaços sagrados clássicos. Em busca de proximidade que se contraponha ao distanciamento físico, os exercícios religiosos fraternos e solidários incentivam à caridade e ações solidárias palpáveis em benefício da coletividade (McLaughlin, 2020, p. 20-21).

Boa parte das lideranças e dos fiéis envidaram esforços para alcançar condições de adaptabilidade e estão seguindo as restrições e orientações sanitárias de manter e ampliar o distanciamento físico e social com o objetivo de conter o avanço da COVID-19 (Nunes, 2020). Contudo, alguns líderes religiosos assumiram posturas resistentes em mudar os hábitos e costumes religiosos, desde a- 
queles que negavam com veemência a existência do vírus, até aqueles que profetizaram sua cura por meio de recursos muitas vezes contrários à ciência.

\begin{abstract}
A resistência em fechar as igrejas encontra eco no Congresso. Presidente da Frente Parlamentar Evangélica, o deputado Silas Câmara (Republicanos-AM) solicitou a reabertura de templos religiosos que foram fechados em outros Estados por recomendação de Governos sob a justificativa de "acolher os desesperados" nos refúgios contra o que chama de "pandemia maligna". Igrejas desafiam recomendação de suspender missas e cultos diante da pandemia do coronavirus (Pires, 2020).
\end{abstract}

Vários líderes religiosos assumiram uma postura negacionista enquanto outros optaram por uma postura reducionista como é possível ser atestado em diversos pronunciamentos de líderes religiosos, ora negando ou minimizando a gravidade da COVID-19, levando as vidas dos fiéis e as suas próprias vidas a situações de risco de contaminação da doença, com a possibilidade de aumentar a disseminação do novo coronavírus. Um exemplo de postura negacionista foi a do Pr. Silas Malafaia que afirmava já no início da pandemia, em março de 2020, que não fecharia a igreja por causa do coronavirus (Barreto Filho, 2020).

\title{
A postura negacionista
}

A postura negacionista sempre vem apoiada em teorias e discursos incoerentes e sem aprofundamentos, em clara oposição aos dados científicos. Assim espalharam o vírus da desconfiança, apoiados em princípios ético-morais que de fácil assimilação para os fiéis já habituados com uma linguagem religiosa fundamentalista. Essa postura alargou e aumentou o fenômeno de desinformação, não apenas por meio deinformações falsas, fake news, como também ambíguas e inconclusivas. O espaço religioso é umespaço fértil para a divulgação de informações, pois são tidos como espaços confiáveis, não somente em função da liderança, como um rabino, pastor(a), padre, imã, monge(a), mas em função dos próprios fiéis, dada afraternidade, o apoio e a confiabilidade(Porreca, 2020, p. 231234).

Assim como se deu em outros segmentos da sociedade como campo politico, por exemplo, também no campo religioso houve resistências relacionadas à admissão da realidade e da gravidade da pandemia do novo coronavirus e isso acabou trazendo consequências desastrosas, com disseminação do vírus, contaminação em massa e morte inclusive de lideranças religiosas. ${ }^{1}$ 
Segundo Porreca:

nem todas as lideranças e adeptos religiosos seguiram as restrições e orientações sanitárias de manter e ampliar o isolamento social ou seguir os protocolos para a volta gradual para conter o avanço do SARS-CoV-2. Alguns líderes religiosos hindus, judeus, cristãos, mulçumanos e budistas em especial, assumiram e mantiveram inúmeras resistências em mudar os hábitos e costumes religiosos, desde aqueles que negavam veementemente a existência do vírus, até aqueles que garantiram a sua cura(Porreca, 2020, p. 236).

Em artigo publicado no dia 20 de maio de 2020, o Jornal A Gazeta, de Vitóri (ES), Nunes (2020), publicou uma série de depoimentos de lideranças religiosas expressando a visão de cada grupo por elas representado, diante da pandemia da COVID-19. Entre os depoimentos estão aqueles de demonstram uma postura negacionista do fenômeno, entendendo simplesmente como o cumprimento das profecias narradas nas Escrituras, apontando como saída apenas que os fiéis devem buscar mais a Deus, ao invés de reconhecer a gravidade do momento e orientar os membros das comunidades em como se proteger do vírus e como podem contribuir para que o vírus não se propague. No mesmo artigo é dito também que é preocupante o fato de que algumas lideranças religiosas estão mais preocupadas com os templos vazios em função da ausência da contribuição do dízimo do que com a vida e o sofrimento dos fiéis.

Para Edebrande Cavalieri, o sentido de religião passa, em boa medida, por essa atitude de acolhimento nos tempos dificeis, mas que não é praticado por todas as lideranças. 'Nessa pandemia, algo que acho perverso é ver alguns líderes que deixam transparecer maior preocupação com os templos vazios em função da ausência da contribuição do dízimo, do que com a vida dos fiéis', lamenta (Nunes, 2020).

Embora tenha sido citado por um pesquisador e não por um líder religioso, a observação é digna de nota e revela uma percepção relevante para o presente artigo.

\section{A postura reducionista}

Outra postura pode ser descrita como reducionista, na qual a gravidade da situação era questionada e houve a disseminação da noção de que somente a fé pela fé, uma fé sobrenatural, que se empenha na busca das certezas e das 
verdades, é capaz de superar os medos, as dúvidas e as angústias. Aqui, percebe-se um afastamento da racionalidade humana e a afirmação de que a ciência éineficaz para alcançar as verdades sobre a pandemia da COVID-19 e que apenas a fé poderia livrar e proteger as pessoas de qualquer vírus, principalmente este novo virus. Essa postura reducionista afirma a impotência do ser humano e sua total incapacidade de se proteger da doença, pois somente alguém superior a estes ser humano poderia protegê-lo e livrá-lo. Logo, não haveria contaminação desde que as pessoas exercitassem pura e simplesmente a fé. Associada à noção da fé, afirmavam que caso fossem utilizados os recursos da vigilância sanitária, o ser humano estaria demonstrando sua desconfiança no Ser Superior e na sua proteção advinda do mesmo, e,deste modo, seriam infiéis e ingratos (Porreca, 2020, p. 236-241).

Apesar de reconhecer que existe algo diferente acontecendo no mundo, um líder religioso afirmou para um jornal da cidade que, "embora seja um momento diferente vivido pela humanidade, para sua religião não há nada de excepcionalidade. Trata-se apenas de uma transição planetária” (Nunes, 2020, p. 2).

Embora admitindo que a humanidade vivia um momento diferenciado no início de 2020, posturas de resistência ao isolamento social foram tomadas por variados grupos de líderes religiosos, incluindo lideranças de igrejas cristãs, entendendo que não havia motivos para um isolamento total. Em função disso, assumiram e rejeitaram o quê e como lhes mais convinham, em relação ao isolamento social e às práticas de prevenção, negando-se, inclusive de tomar as medidas protocolares orientadas pelas autoridades sanitárias. Esses grupos resistiram parcialmente às mudanças, não as contrapunha de forma clara e autêntica, tinha consciência da gravidade da contaminação e da doença, era cauteloso e mantinha as mesmas atividades religiosas, sem conflitos e, de maneira não explícita, procurava brechas sanitárias e religiosas para manter o que, ideologicamente individual, impunha como prática religiosacomum(Porreca,2020,p. 238).

\section{A postura consciente}

Há também aquelas religiões que entenderam a gravidade do momento e buscaram alternativas interessantes para superar o isolamento e distanciamento imposto pela pandemia da COVID - 19. Segundo Porreca, "a maioria das religiões presentes no mundo procuraram adaptar-se e reinventar-se vertiginosamente 
frente às mudanças de escala global geradas pelo novo Coronavírus(SARS-CoV2)" (2020, p. 229).

Seguindo as orientações das autoridades de saúde que alertaram para o perigo das aglomerações e a necessidade de isolamento e distanciamento social, muitas comunidades religiosas optaram por fechar as portas de seus ambientes de culto e orientar seus membros a permanecerem em suas casas, enquanto as lideranças foram em busca de alternativas para continuar o contato com os integrantes das comunidades. A grande maioria das religiões, sobretudo as Igrejas Cristãs, reconhecendo a gravidade do problema e os riscos que seria a manutenção dos encontros públicos, tomaram providências no sentido de suprir as necessidades dos membros de suas comunidades utilizando as novas tecnologias e desenvolvendo redes de solidariedade.Fabiano Santos, presidente da Fraternidade Espírita, (Nunes, 2020) afirmou que sua comunidade está ensinando seus membros a fazerem lives, palestras públicas, atendimentos a distância, como utilizar os encontros virtuais para evangelizar, etc. (Nunes, 2020). Felizmente a maioria dos líderes religiosos entrevistados pela reportagem do jornal entende que o momento vivido pela humanidade nesse momento de profunda crise espiritual, social e econômica e, em função disso, tem se adaptado para ajudar as pessoas em todas as áreas possiveis, desde a transmissão on line de suas atividades até a mobilização de redes de solidariedade visando suprir as demandas mais primárias das pessoas que, em função da pandemia, perderam seus empregos ou estão impedidas de trabalhar (Nunes, 2020).

Não resta dúvidas de que esse movimento de retorno para casa e de fechamento dos lugares públicos de encontros religiosos trouxe e ainda trará desdobramentos, quebrando paradigmas e promovendo mudanças na rotina das comunidades e na vida das pessoas. Porreca afirma:

A novidade de se rezar fora do templo, da mesquita ou sinagoga; de se celebrar uma páscoa sem missa; realizar um exorcismo em casa; ter ritos funerais diminuídos; não se comemorar o fi $\mathrm{m}$ do Ramadã; não realizar as costumeiras peregrinações e rituais de purifi cações em rios; cancelar cerimônias de casamentos e outras situações religiosas inusitadas e inesperadas, mesmo após a diminuição da disseminação do vírus e com os protocolos de retorno gradual às celebrações ou aos ritos presenciais que acontecem timidamente, impactaram as religiões. (2020, p. 229). 
Esse impacto constitui-se também numa oportunidade para a revisão de determinadas práticas e também em sua teologia gerando "um movimento tecnológico e teológico nas antigas estruturas e dinâmicas religiosas, convencionadamente institucionalizadas, obrigando a reconstrução de diferentes estilos de vida e formas de se exercer a religiosidade" (Porreca, 2020, p. 230). Claro que isso custa um alto preço para as pessoas que têm nos lugares destinados aos rituais religiosos um espaço de encontro, tanto com as divindades como também com o próximo, lugares de pertença, de suprimento de suas necessidades multidimensionais, indo dos aspectos da espiritualidade até as necessidades básicas de alimentação e higiene (Porreca, 2020, p. 232).

Outro dado importante que serve de subsídio para uma reflexão no período da pandemia e pós-pandemia foi o caso das religiões que demandam de mediação de líderes. Como Porreca destaca:

As Religiões mediadas por um(a) líder tiveram que se adaptar a um novo modelo, cuja estrutura, de certa forma, precisou ser redimensionada, concedendo aos adeptos um considerável protagonismo e autonomia nas celebrações e nos ritos que eram assistidos em casa e no gerenciamento de muitas atividades religiosas. Os adeptos tiveram que assumir para si mesmos papéis diferentes e assumir incumbências religiosas, que antes eram atribuídas aos líderes religiosos (Porreca, 2020, p. 234).

O que em princípio se constituiu num problema desafiador para os membros das comunidades pode se transformar numa descoberta interessante que servirá de aprendizado e aquisição de novas posturas a partir do fim da pandemia, diante do reconhecimento da competência de cada indivíduo no desenvolvimento de sua própria espiritualidade com liberdade e autonomia, o que na teologia cristã protestante se entende por sacerdócio universal dos santos (Kivitz, 2002, p. 49). Embora a dimensão comunitária da fé tenha relevância vital para os cristãos, reconhece-se que cada discípulo/a de Jesus Cristo tem autonomia para desenvolver um relacionamento íntimo e pessoal com o divino.

\section{Considerações finais}

A crise sanitária e social desencadeada pela COVID-19 não só proporcionou mudanças nas atividades religiosas como também estimulou as religiões a repensarem seus modelos estruturais. Permitiu divisar as atividades religiosas 
mais no campo tecnológico e menos centradas e dependentes da liderança religiosa. Em tempos pandêmicos de distanciamento fisico e social, a casa voltou a ser um espaço sagrado, "um lugar religioso, um espaço celebrativo para o encontro com a(s) divindade(s), chancelada pelas lideranças religiosas" (Porreca, 2020, p. 238).

As ações e reações religiosas nesse tempo impensado de pandemia da COVID-19, com contornos limítrofes para a existência humana, deveriam provocar profunda reflexão com relação à convivência com o outro. Afinal, individual e coletivamente, nós, seres humanos, podemos ser uma companhia de risco, ao adotarmos posturas negacionistas ou reducionistas. "Promover a desinformação, o fundamentalismo e o desprezo à ciência é uma atitude, no mínimo, irresponsável, à medida que, neste cenário de pandemia, ações como essas colocam em risco toda a coletividade" (Porreca, 2020, p. 238).

Ao invés de negar ou reduzir a importância do impacto da pandemia da COVID-19 a recomendação é que as lideranças religiosas aproveitem a oportunidade para avaliar a relevância das doutrinas e práticas de suas comunidades, abrindo espaço para novos paradigmas, que possibilitem novas crenças e novas práticas, mais alinhadas com as demandas da sociedade contemporânea.

\section{Referências bibliográficas}

BARKER, Joel A. Paradigms. Nova York: Harper Business, 1992.

BARRETO FILHO, Herculano. Silas Malafaia diz que não vai fechar igreja por causa do coronavírus.Uol.Rio de Janeiro, 14 de março de 2020. Disponível em: https://noticias.uol.com.br/saude/ultimas-noticias/redacao/2020/03/14/silasmalafaia-diz-que-nao-vai-fechar-igreja-por-causa-do-coronavirus.htm?cmpid=co pia ecola2020. Acesso em 22 de fevereiro de 2021.

BARRY, John M. A grande gripe: a história da gripe espanhola, a pandemia mais mortal de todos os tempos. Rio de Janeiro: Intrínseca, 2020.

BERGER, Peter L. O dossel sagrado: elementos para uma teoria sociológica da religião. $2^{\circ}$ ed. São Paulo: Paulus, 1995.

CUNHA, Magali do N. Do púlpito às mídias sociais: evangélicos na política e ativismo digital. Curitiba: Prisma, 2017.

FREIRE, Adriana do A. Quando o fiel vira fã: celebridades religiosas e interações no Facebook. Tese (doutorado em Comunicação). Recife: Universidade Federal de Pernambuco, 2017.

HEIDEGGER, Martin. Ser e tempo. Rio de Janeiro: Vozes, 1998. 
KIVITZ, Ed René. Quebrando paradigmas. 5 ed. São Paulo: Abba Press, 2002.

KUHN, Thomas S. A estrutura das revoluções científicas. $13^{\circ}$ ed. São Paulo: Perspectiva, 2013.

MAQBOOL, Aleem. Coronavirus: pastor que chamou epidemia de 'histeria' morre após pregar em carnaval. BBC News. Washington,07 de abril de 2020. Disponivel em: https://www.bbc.com/portuguese/geral-52193957. Acesso em 22 de fevereiro de 2021.

MARTINO, José. 1348: a peste negra. Atibaia: Excalibur, 2017.

McLAUGHLIN, Levi. Japanese religious responses to COVID-19: a preliminary report. The Asia-Pacific Journal, v.18, n. 3, 2020. pp. 1-23. Disponivel em: https://repository.lib.ncsu.edu/bitstream/handle/1840.20/37530/McLaughlin \%20-\%20Japan\%20COVID.pdf?sequence=1\&isAllowed=y. Acesso em $17 \mathrm{de}$ outubro de 2020.

MORIN, Edgar. Os sete saberes necessários à educação do futuro. $3^{\circ}$ ed. São Paulo: Cortez; Brasília: UNESCO, 2001.

NUNES, Aline. A fé explica: as respostas das religiões sobre a pandemia do coronavírus. Jornal a Gazeta. Vitória, 23 de maio de 2020. Disponível em: https://www.agazeta.com.br/es/cotidiano/a-fe-explica-as-respostas-das-

religioes-sobre-a-pandemia-do-coronavirus-0520. Acesso em 22 de fevereiro de 2021.

PIRES, Breiller. Igrejas desafiam recomendação de suspender missas e cultos diante da pandemia do coronavirus. El País. São Paulo, 19 de março de 2020. Disponivel em:https://brasil.elpais.com/brasil/2020-03-20/igrejas-desafiam-re comendacao-de-suspender-missas-e-cultos-diante-da-pandemia-docoronavirus.html. Acesso em 22 de fevereiro de 2020.

PORRECA, Wladimir. As religiões e a COVID-19: enfrentamentos e adaptações. In: GUIMARÃES, Ludmila de Vasconcelos M.; CARRETEIRO, Teresa Cristina; NASCIUTTI, Jacyara Rochael (org.). Janelas da Pandemia. Belo Horizonte: Instituto DH, 2020. pp. 229-241.

SNYDER, Howard. Vinho novo, odres novos: vida nova para a igreja. São Paulo: ABU, 1977.

\footnotetext{
1 Ao longo da pandemia foram comuns manchetes em jornais semelhantes a esta: "Coronavírus: pastor que chamou epidemia de 'histeria' morre após pregar em carnaval” (Maqbool, 2020).
}

Recebido em 20/10/2020

Aceito para publicação em 16/02/2021 